\title{
Rapid titrimetric and spectrophotometric determination of ofloxacin in pharmaceuticals using $\mathrm{N}$-bromosuccinimide
}

\author{
Kanakapura Basavaiah Vinay, Hosakere Doddarevanna Revanasiddappa, Okram Zenita Devi, \\ Pavagada Jagannathamurthy Ramesh, Kanakapura Basavaiah*
}

Department of Chemistry, University of Mysore, Manasagangothri, India

\begin{abstract}
One titrimetric and two spectrophotometric methods have been described for the determination of ofloxacin (OFX) in bulk drug and in tablets, employing N-Bromosuccinimide as an analytical reagent. The proposed methods involve the addition of a known excess of NBS to OFX in acid medium, followed by determination of unreacted NBS. In titrimetry, the unreacted NBS is determined iodometrically, and in spectrophotometry, unreacted NBS is determined by reacting with a fixed amount of either indigo carmine (Method A) or metanil yellow (Method B). In all the methods, the amount of NBS reacted corresponds to the amount of OFX. Titrimetry allows the determination of 1-8 $\mathrm{mg}$ of OFX and the calculations are based on a 1:5 (OFX:NBS) reaction stoichiometry. In spectrophotometry, Beer's law is obeyed in the concentration ranges $0.5-5.0 \mu \mathrm{g} / \mathrm{mL}$ for method $\mathrm{A}$ and $0.3-3.0 \mu \mathrm{g} / \mathrm{mL}$ for method $\mathrm{B}$. The molar absorptivities are calculated to be $5.53 \times 10^{4}$ and $9.24 \times 10^{4} \mathrm{~L} / \mathrm{mol} / \mathrm{cm}$ for method A and method B, respectively. The methods developed were applied to the assay of OFX in tablets, and results compared statistically with those of a reference method. The accuracy and reliability of the methods were further ascertained by performing recovery tests via the standard-addition method.
\end{abstract}

Uniterms: Ofloxacin/determination. Titrimetry/quantitative analysis. Spectrophotometry/quantitative analysis. $\mathrm{N}$-Bromosuccinimide. Tablets/quantitative analysis.

\begin{abstract}
Descrevem-se métodos, um titulométrico e dois espectrofotométricos, para a determinação de ofloxacino (OFX) na matéria-prima e em comprimidos, empregando a $N$-bromossuccinimida (NBS) como reagente analítico. Os métodos propostos envolvem a adição de excesso conhecido de NBS ao OFX, em meio ácido, seguida de determinação do NBS que não reagiu. Na titulometria, o NBS que não reagiu é determinado iodometricamente e na espectrofotometria, o NBS que não reagiu é determinado pela reação com quantidade fixa de índigo carmim (Método A) ou amarelo de metanila (Método B). Em todos os métodos, a quantidade de NBS que reagiu corresponde à quantidade de OFX. A titulometria permite a determinação de 1-8 mg de OFX e os cálculos se baseiam na estequiometria de reação de 1:5 (OFX:NBS). $\mathrm{Na}$ espectrofotometria, a Lei de Beer é obedecida nas faixas de concentração de $0,5-5,0 \mu \mathrm{g} / \mathrm{mL}$, para o método A, e de 0,3-3,0 $\mu \mathrm{g} / \mathrm{mL}$, para o método $\mathrm{B}$, respectivamente. Os métodos desenvolvidos foram aplicados para o teste de OFX em comprimidos e os resultados foram comparados estatisticamente com aqueles do método de referência. A precisão e a confiabilidade dos métodos foram, posteriormente, verificadas por meio dos testes de recuperação via método de adição de padrão.
\end{abstract}

Unitermos: Ofloxacino/determinação. Titulometria/análise quantitativa. Espectrofotometria/análise quantitativa. $N$-Bromossuccinimida. Comprimidos/análise quantitativa.

\section{INTRODUCTION}

Ofloxacin (OFX), (RS)-7-fluoro-2-methyl-6-(4-methylpiperazine-1-yl)-10-oxo-4-oxa-1-azatricyclo[7.3.1.0 $\left.0^{5,13}\right]$

*Corresponding author: Kanakapura Basavaiah. Department of Chemistry, University of Mysore, Manasagangotri, Mysore-570006, India. E-mail: basavaiahk@yahoo.co.in trideca-5(13),6,8,11-tetraene-11-carboxylic acid (Figure 1), is a fluoroquinolone antibiotic considered to be a second-generation fluoroquinolone. It is active against both Gram-positive and Gram-negative bacteria and functions by inhibiting DNA gyrase, a type II topoisomerase, and topoisomerase IV, (Drlica, Zhao, 1997) which is an enzyme necessary to separate replicated DNA, thereby inhibiting 
<smiles>CC1COc2c(N3CCN(C)CC3)c(F)cc3c(=O)c(C(=O)O)cn1c23</smiles>

FIGURE 1 - Chemical structure of OFX.

cell division. This drug is official in the United States Pharmacopoeia (USP, 2004) and the British Pharmacopoeia (BP, 2003), which recommend non-aqueous titrimetry (USP, 2004; BP, 2003) and HPLC (USP, 2004) techniques for its assay in bulk and dosage forms.

A review of the literature revealed that various analytical methods for the determination of OFX in bulk and pharmaceutical dosage forms have been reported. These include spectrofluorometry (Salem, 2005), atomic absorption spectrometry (Salem, 2005), capillary electrophoresis (Abdalla et al., 2008; Sun, Wu, 1999), HPLC (Arjekar et al., 1996; Carlucci et al., 1993; Kalta, Sharma, Chaturvedi, 2008; Sinde, Desai, Tendolkar, 1998), HPTLC (Srividya, Cardoza, Amin, 2003), chemiluminescence (Francis, Paul, Adcock, 2005), as well as electroanalytical (Tamer, 1990; Tuncel, Atkosar, 1992; Zhou, Pan, 1995) and microbiological methods (Silveria, Schapoval, 2002). Some of these methods have sufficient sensitivity to determine lower concentrations of the drug. However, these methods involve several manipulation steps which are not simple for routine analysis of pharmaceutical formulations and require sophisticated instruments.

Titrimetry and visible spectrophotometry may serve as useful alternatives to many of the aforesaid sophisticated techniques because of their cost-effectiveness, ease of operation, sensitivity, remarkable accuracy, precision and wide applicability. The literature search revealed that no titrimetric methods have yet been reported for the determination of OFX.

Visible spectrophotometric methods based on diverse reaction chemistry have been proposed for the assay of OFX in pharmaceuticals. The method based on the formation of pink colored chromogen by the reaction between OFX and citric acid-acetic anhydride (Patel et al., 2007) has been reported. Extractive spectrophotometric procedures based on the formation of yellow colored ion pair complex (Issa, 1997) with bromophenol blue (BPB), bromothymol blue (BTB) and bromocresol purple (BCP); and red colored ion-pair complex (Sastry, Rama, Siva Prasad, 1995) with tropaeolin and supracene violet 3B, have been used for the assay of OFX. Other visible spec- trophotometric methods based on reactions such as complex formation reaction with Fe (III) nitrate nonahydrate (Eboka, Aigbavboa, Akerele, 1997), yellow complex with iron (III) chloride in $\mathrm{HCl}$ medium (Mathur et al., 1992); and oxidative coupling reaction with $\mathrm{Ce}(\mathrm{IV})-\mathrm{MBTH}$ (Sastry, Rama, Siva Prasad, 1995), were reported for the assay of OFX. Most of the visible spectrophotometric methods above have one or more inherent disadvantages such as use of heating step, use of organic solvents, close $\mathrm{pH}$ control, poor sensitivity and use of expensive reagents, as indicated in Table I.

The aim of the present investigation was to develop simple, sensitive and cost-effective methods for the determination of OFX in pure and dosage forms using titrimetric and spectrophotometric techniques. The methods utilized NBS, indigo carmine and metanil yellow as reagents. The methods developed offer the advantages of simplicity, sensitivity, speed, accuracy and precision without the need for costly equipment/chemicals.

\section{MATERIAL AND METHODS}

\section{Apparatus}

All absorbance measurements were taken on a Systronics model 106 digital single beam spectrophotometer (Ahmedabad, India) equipped with 1-cm matched quartz cells.

\section{Material and reagents}

All chemicals and reagents used were of analytical or pharmaceutical grade and distilled water was used to prepare the solutions.

\section{- Standard OFX Solution}

Pharmaceutical grade OFX, certified to be $99.98 \%$ pure, was received as a gift from Cipla India Ltd, Mumbai, India, and used as received. Standard OFX solutions $(1 \mathrm{mg} / \mathrm{mL}, 10$ and $6 \mu \mathrm{g} / \mathrm{mL}$ ) were prepared by dissolving a calculated quantity of pure drug in $0.1 \mathrm{M} \mathrm{HCl}$.

Two brands of tablets containing OFX, Zenflox-400 (Mankind Pharma Pvt Ltd., New Delhi, India) and Ofloxin-400 (J. B. Chemicals and Pharmaceuticals Ltd, Mumbai, India), used in the investigation were purchased from local commercial sources.

N-Bromosuccinimide (NBS): an approximately $0.02 \mathrm{M}$ NBS solution was prepared, standardized (Berka, Vulterin, Zyoka, 1965) and used in titrimetry. The NBS solution $(0.02 \mathrm{M})$ was further diluted to a concentration of 150 and $100 \mu \mathrm{g} / \mathrm{mL}$ for spectrophotometric method A and method $\mathrm{B}$, respectively. 
TABLE I - Comparison of performance characteristics of present methods with published methods

\begin{tabular}{|c|c|c|c|c|c|c|}
\hline $\begin{array}{l}\text { Sl. } \\
\text { No. }\end{array}$ & Reagent/s used & Methodology & $\begin{array}{l}\lambda_{\max } \\
(\mathrm{nm})\end{array}$ & $\begin{array}{c}\text { Linear range } \\
(\mu \mathrm{g} / \mathrm{mL}) \\
(\varepsilon=\mathrm{L} / \mathrm{mol} / \mathrm{cm}) \\
\end{array}$ & Remarks & Ref \\
\hline 2 & $\begin{array}{l}\text { a) Bromophenol blue } \\
\text { b) Bromothymol blue } \\
\text { c) Bromocresol purple }\end{array}$ & $\begin{array}{l}\text { Yellow colored 1:1 } \\
\text { ion-pair complex } \\
\text { extractable in } \\
\text { chloroform was } \\
\text { measured }\end{array}$ & $\begin{array}{l}415 \\
410\end{array}$ & $\begin{array}{c}5-25 \\
\left(\varepsilon=1.04 \times 10^{4}\right) \\
2-15 \\
\left(\varepsilon=2.01 \times 10^{4}\right) \\
2-20 \\
\left(\varepsilon=1.04 \times 10^{4}\right)\end{array}$ & $\begin{array}{c}\text { Required close } \mathrm{p}^{\mathrm{H}} \\
\text { control and involved } \\
\text { extraction steps organic } \\
\text { solvent is used }\end{array}$ & Issa, 1997 \\
\hline 3 & a) Tropaeolin 000 (TP 000) & $\begin{array}{l}\text { Red colored ion-pair } \\
\text { complex extractable } \\
\text { in chloroform was } \\
\text { measured } \\
\text { Chloroform } \\
\text { extractable ion-pair } \\
\text { complex measured }\end{array}$ & 485 & $\begin{aligned} & 2.5-30 \\
(\varepsilon= & \left.8.24 \times 10^{3}\right) \\
& \\
& 2.5-25 \\
(\varepsilon= & \left.1.09 \times 10^{4}\right)\end{aligned}$ & $\begin{array}{c}\text { Used of organic } \\
\text { solvent, required } \\
\text { close } \mathrm{pH} \text { control and } \\
\text { involved extraction } \\
\text { steps }\end{array}$ & $\begin{array}{c}\text { Sastry, Rama, } \\
\text { Siva prasad, } \\
1995\end{array}$ \\
\hline 4 & Iron(III) nitrate & $\begin{array}{c}\text { Amber colored } \\
\text { complex was measured }\end{array}$ & 370 & $\begin{array}{c}0-62.5 \\
\left(A_{1 \%}=207\right)\end{array}$ & Buffers used. & $\begin{array}{c}\text { Eboka, } \\
\text { Aigbavboa, } \\
\text { Akerele, } 1997 \\
\end{array}$ \\
\hline 5 & Iron(III) chloride/HCl & $\begin{array}{l}\text { Yellow complex } \\
\text { measured }\end{array}$ & 410 & $20-160$ & $\begin{array}{l}\text { Less sensitive, } \\
\text { significant blank } \\
\text { absorbance. }\end{array}$ & $\begin{array}{c}\text { Mathur et al., } \\
1992\end{array}$ \\
\hline
\end{tabular}

- Sodium thiosulphate $(0.04 \mathrm{M})$

This was prepared by dissolving $9.93 \mathrm{~g}$ of chemical (S. d. Fine Chem. Ltd., Mumbai, India) in one liter of water for use in titrimetry.

\section{- $\mathrm{HCl}(1 \mathrm{M}, 2 \mathrm{M}$ and $5 \mathrm{M})$}

Concentrated $\mathrm{HCl}$ (S. D. Fine Chem, Mumbai, India, sp. gr. 1.18) were appropriately diluted with water to attain the required concentrations.

\section{- Potassium iodide (10\%)}

This was prepared by dissolving $10 \mathrm{~g}$ of the chemical
(Merck, Mumbai, India) in $100 \mathrm{~mL}$ of water and used in titrimetry.

\section{- Starch indicator (1\%)}

One $g$ of the reagent (Merck, Mumbai, India) was made into a paste and poured into $100 \mathrm{~mL}$ of boiling water, boiled for $1 \mathrm{~min}$, cooled and used for titrimetry.

- Indigo carmine $(200 \mu \mathrm{g} / \mathrm{mL})$ and metanil yellow $(50 \mu \mathrm{g} / \mathrm{mL})$

The dye solutions were prepared (S.D. Fine Chem, Mumbai, India, dye content 90\%) in water and filtered. 


\section{General procedure}

\section{- Titrimetry}

Different volumes (1-8 $\mathrm{mL})$ of standard solution containing $1 \mathrm{mg} / \mathrm{mL}$ OFX were accurately measured and transferred into a $100 \mathrm{~mL}$ titration flask and the volume was made up to $10 \mathrm{~mL}$ with $0.1 \mathrm{M} \mathrm{HCl}$. Two $\mathrm{mL}$ of $2 \mathrm{M}$ $\mathrm{HCl}$ and $10 \mathrm{~mL}$ of NBS $(0.02 \mathrm{M})$ were pipetted into the flask, the content mixed and set aside for $10 \mathrm{~min}$. Subsequently, $5 \mathrm{~mL}$ of $10 \%$ potassium iodide solution was added, and the liberated iodine was titrated against sodium thiosulphate $(0.04 \mathrm{M})$ using starch indicator. A blank titration was performed under identical conditions.

The amount of OFX in the aliquot was computed from the following formula:

$$
\text { Amount }(\mathrm{mg})=\mathrm{VM}_{\mathrm{w}} \mathrm{S} / \mathrm{n}
$$

where $\mathrm{V}=\mathrm{mL}$ of NBS reacted; $\mathrm{M}_{\mathrm{w}}=$ relative molecular mass of drug; $\mathrm{S}=$ concentration of NBS, moles/L; $\mathrm{n}=$ number of moles of NBS reacting with each mole of OFX.

\section{Spectrophotometry}

\section{- Method A}

Different aliquots, $0.5,1.0,2.0,3.0,4.0$ and $5.0 \mathrm{~mL}$ of standard OFX solution $(10 \mu \mathrm{g} / \mathrm{mL})$ were transferred into a series of $10 \mathrm{~mL}$ standard volumetric flasks and the total volume in each flask was adjusted to $5 \mathrm{~mL}$ with $0.1 \mathrm{M}$ $\mathrm{HCl}$. To each flask, $1 \mathrm{~mL}$ of $1 \mathrm{M} \mathrm{HCl}$ followed by $1 \mathrm{~mL}$ of $150 \mu \mathrm{g} / \mathrm{mL}$ NBS were added. The content of each flask was mixed well and set aside for 15 minutes with occasional shaking. Finally, $1 \mathrm{~mL}$ of $200 \mu \mathrm{g} / \mathrm{mL}$ indigo carmine was added and the volume was made up to the mark with distilled water after $5 \mathrm{~min}$. The absorbance was measured at $610 \mathrm{~nm} V s$ reagent blank prepared in a similar manner.

\section{- Method B}

Different aliquots $(0.5,1.0,2.0,3.0,4.0$ and 5.0$) \mathrm{mL}$ of standard $6 \mu \mathrm{g} / \mathrm{mL}$ OFX solution were accurately measured and transferred into a series of $10 \mathrm{~mL}$ calibrated flasks by means of a microburette and total volume adjusted to $5 \mathrm{~mL}$ with $0.1 \mathrm{M} \mathrm{HCl}$. To each flask, $1 \mathrm{~mL}$ of $5 \mathrm{M} \mathrm{HCl}$ followed by $1 \mathrm{~mL}$ of $100 \mu \mathrm{g} / \mathrm{mL}$ NBS, was added using a microburette. The content of each flask was mixed well and set aside for 10 minutes. Lastly, $1 \mathrm{~mL}$ of $50 \mu \mathrm{g} / \mathrm{mL}$ metanil yellow was added to each flask and mixed well. The volume was made up to the mark with distilled water after $5 \mathrm{~min}$ and the absorbance was measured at $530 \mathrm{~nm}$ $V S$ reagent blank prepared in a similar manner.

Calibration graphs were prepared by plotting the increasing absorbance values versus concentrations of OFX. The concentration of the unknown was read from the respective calibration graph or deduced from the regression equation derived using the Beer's law data.

\section{Procedure for the assay of ofloxacin in pharmaceutical preparations}

Twenty tablets were weighed accurately and ground into a fine powder. A quantity of the powder containing $100 \mathrm{mg}$ of OFX was accurately weighed into a $100 \mathrm{~mL}$ calibrated flask and $60 \mathrm{~mL}$ of $0.1 \mathrm{M} \mathrm{HCl}$ was added. The content was shaken for about $20 \mathrm{~min}$; volume diluted to the mark with $0.1 \mathrm{M} \mathrm{HCl}$ and mixed, and filtered using a Whatman No. 42 filter paper. The first $10 \mathrm{~mL}$ portion of the filtrate was discarded, and a convenient aliquot was taken and the assay completed according to the titrimetric procedure described earlier. The tablet extract containing OFX at a concentration of $1 \mathrm{mg} / \mathrm{mL}$ was then diluted stepwise with $0.1 \mathrm{M} \mathrm{HCl}$ to obtain working concentrations of $10 \mu \mathrm{g} / \mathrm{mL}$ and $6 \mu \mathrm{g} / \mathrm{mL}$ in OFX for spectrophotometric methods A and B, respectively. A convenient aliquot was then subjected to analysis by the spectrophotometric procedures described above.

\section{Placebo blank analysis}

Based on the approximate composition of excipients normally added in the tablet, a placebo blank of the composition: talc (5 mg), starch (5 mg), acacia (5 mg), methyl cellulose $(10 \mathrm{mg})$, sodium citrate $(5 \mathrm{mg})$, magnesium stearate $(5 \mathrm{mg})$ and sodium alginate $(5 \mathrm{mg})$ was made and its solution prepared as described under 'Procedure for the assay of OFX in pharmaceutical preparations', and then subjected to analysis using the procedures described above.

\section{Procedure for the determination of OFX in synthetic mixture}

A volume of $100 \mathrm{mg}$ of OFX was added to the placebo blank of the composition described above, which was then homogenized, transferred to a $100 \mathrm{~mL}$ standard flask and solution prepared as described under tablets. The solution was mixed well and filtered using a Whatman No. 42 filter paper. The resulting solution was assayed $(n=5)$ by titrimetry according to the procedure described above. The synthetic mixture solution $(1 \mathrm{mg} / \mathrm{mL}$ in OFX) was then diluted stepwise with $0.1 \mathrm{M} \mathrm{HCl}$ to obtain working concentrations of $10 \mu \mathrm{g} / \mathrm{mL}$ and $6 \mu \mathrm{g} / \mathrm{mL}$ in OFX for spectrophotometric method A and method B, respectively. A convenient aliquot was then subjected to analysis. The analysis was used to study the interferences of excipients such as talc, starch, acacia, methyl cellulose, sodium citrate, magnesium stearate and sodium alginate. 


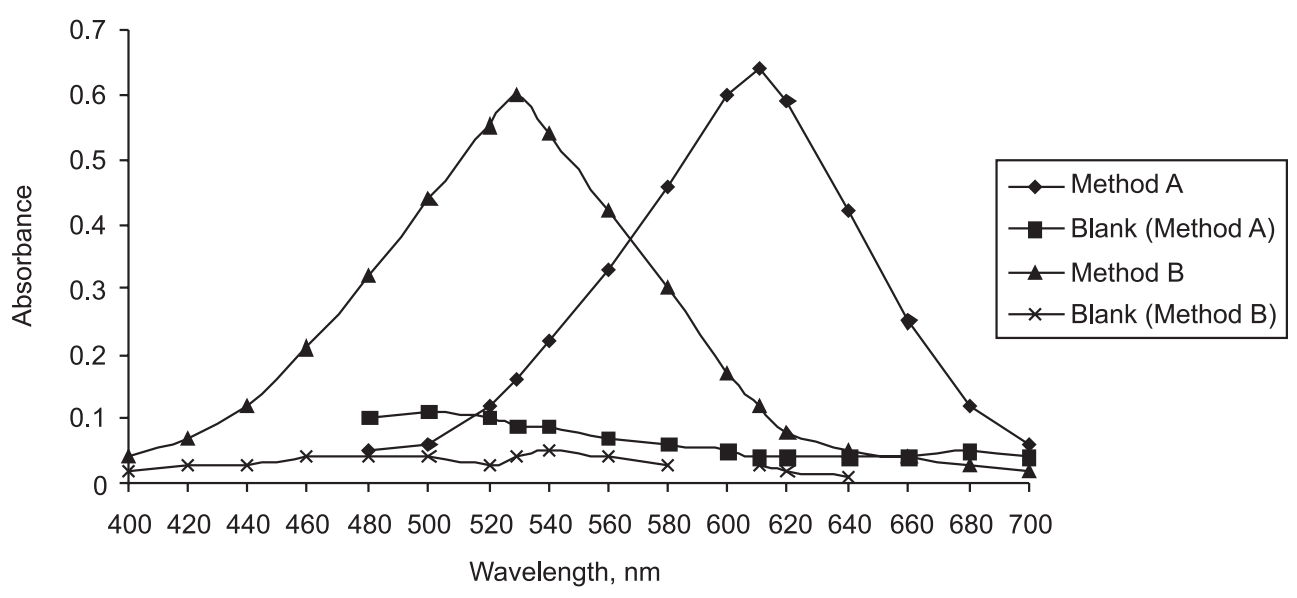

FIGURE 2 - Absorption spectra $(4.0 \mu \mathrm{g} / \mathrm{mL}$ OFX in method A and $2.4 \mu \mathrm{g} / \mathrm{mL}$ in method B).

\section{RESULTS AND DISCUSSION}

A close examination of the literature search presented in the introduction reveals that NBS has not yet been used for the spectrophotometric determination of OFX. NBS is a strong oxidizing agent and perhaps the most important positive bromine containing organic compound; it is used for the specific purpose of brominating alkenes at the allylic position (Morrison, Boyd, 2007). The present work involves the bromination of OFX by NBS followed by determination of surplus
NBS after allowing the bromination reaction to complete. In titrimetry, the unreacted NBS is determined iodometrically, while in spectrophotometric methods, it is determined by reacting with a fixed amount of either indigo carmine and measured at $610 \mathrm{~nm}$ (Figure 2) or metanil yellow and measured at $530 \mathrm{~nm}$ (Figure 2). The spectrophotometric methods make use of the bleaching action of NBS on either of the two dyes, where the discoloration is caused by oxidative destruction of the dye. The tentative reaction scheme of titrimetric and spectrophotometric methods methods is shown in<smiles>[R]OCC1COc2c(N3CCN(C)CC3)c(F)cc3c(=O)c(C(=O)O)cn1c23</smiles>

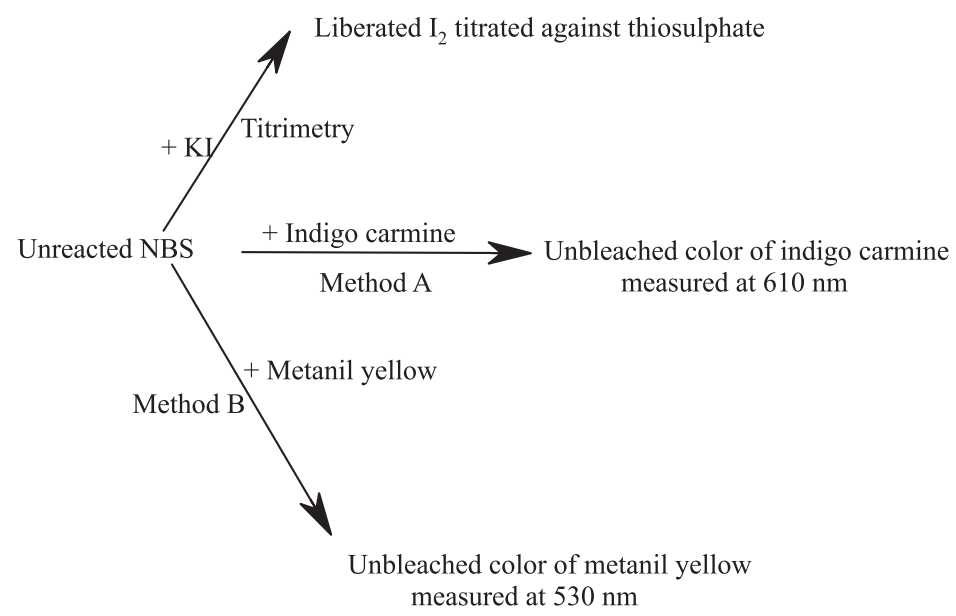

SCHEME I - Tentative reaction scheme for titrimetry, spectrophotometric method A and method B. 
Scheme 1. The bromination of OFX will take place in position $\alpha$ to the carbonyl group (Hassan et al., 2007).

\section{Titrimetry}

Direct titration of OFX with NBS in acid medium was not successful. However, a back titrimetric assay was found to be possible when the reactants were allowed to stand for some time in acid medium. The reaction stoichiometry was found to be 1:5 (OFX: NBS). Reproducible and stoichiometric results were obtained when $\mathrm{HCl}$ medium was employed. A two $\mathrm{mL}$ volume of $2 \mathrm{M} \mathrm{HCl}$ in a total volume of $22 \mathrm{~mL}(0.18 \mathrm{M})$ was found optimal; although the stoichiometry reaction was unaffected in the concentration range of $0.09-0.27 \mathrm{M} \mathrm{HCl}$. The bromination reaction was found to be complete and quantitative in 10 min and contact time up to $20 \mathrm{~min}$ had no effect on the stoichiometry or the results. Hence, the reaction time of $10 \mathrm{~min}$ was established. A $10 \mathrm{~mL}$ aliquot of $0.02 \mathrm{M}$ NBS solution was found adequate for quantitative bromination of OFX in the range determined of 1-8 mg.

\section{Spectrophotometric methods}

The ability of NBS to brominate OFX and bleach the colors of indigo carmine and metanil yellow dyes has been used for the indirect spectrophotometric assay of the drug. Preliminary experiments were performed to determine the maximum concentration of indigo carmine or metanil yellow in the acid medium employed where this was found to be $20 \mu \mathrm{g} / \mathrm{mL}$ and $5 \mu \mathrm{g} / \mathrm{mL}$ for indigo carmine and metanil yellow, respectively. An NBS concentration of $15 \mu \mathrm{g} / \mathrm{mL}$ was found optimum to bleach the blue color produced by $20 \mu \mathrm{g} / \mathrm{mL}$ indigo carmine, whereas in the case of metanil yellow, $10 \mu \mathrm{g} / \mathrm{mL}$ NBS was sufficient to destroy the pink color of $5 \mu \mathrm{g} / \mathrm{mL}$ metanil yellow. Hence, different amounts of OFX reacted with $15 \mu \mathrm{g} / \mathrm{mL}$ NBS in method $\mathrm{A}$, and $10 \mu \mathrm{g} / \mathrm{mL}$ NBS in method B.

Hydrochloric acid was found to be the ideal medium for the bromination of OFX by NBS as well as the latter's determination employing either dye. In both the methods, the reaction between OFX and NBS was unaffected when $0.5-3.0 \mathrm{~mL}$ each of $1 \mathrm{M} \mathrm{HCl}$ (method A) and $5 \mathrm{M} \mathrm{HCl}$ (method B) in a total volume of $10 \mathrm{~mL}$ was used. Hence, $1 \mathrm{~mL}$ each of $1 \mathrm{M} \mathrm{HCl}$ in method A and $5 \mathrm{M} \mathrm{HCl}$ in method $\mathrm{B}$ was used for both the steps. For a quantitative reaction between OFX and NBS, contact times of $15 \mathrm{~min}$ and $10 \mathrm{~min}$ were found necessary in method A and method B, respectively, and constant absorbance readings were obtained when contact times were extended up to $45 \mathrm{~min}$ in method $\mathrm{A}$, and $30 \mathrm{~min}$ in method B. A standing time of 5 min was necessary in both the methods for the bleaching of the dye color by the residual NBS. The measured color was found to be stable for several hours in the presence of the reaction products in both methods.

\section{Method validation procedures}

The proposed methods have been validated for linearity, sensitivity, precision, accuracy, selectivity and recovery.

\section{Linearity and Sensitivity}

Over the range investigated (1-8 $\mathrm{mg})$, fixed stoichiometry of 1:5 (OFX: NBS) was obtained in titrimetry, which served as the basis for calculations. In spectrophotometry, under optimum conditions a linear relation was obtained between absorbance and concentration of OFX in the range of $0.5-5.0 \mu \mathrm{g} / \mathrm{mL}$ (method A) and $0.3-3.0 \mu \mathrm{g} / \mathrm{mL}$ (method B) (Figure 3). The calibration graph is described by the equation:

$$
\mathrm{Y}=\mathrm{a}+\mathrm{b} \mathrm{X}
$$

(where $\mathrm{Y}=$ absorbance, $\mathrm{a}=$ intercept, $\mathrm{b}=$ slope and $\mathrm{X}=$ concentration in $\mu \mathrm{g} / \mathrm{mL}$ ) obtained by the method of least squares. Correlation coefficient, intercept and slope for the calibration data are summarized in Table II. Sensitivity parameters such as apparent molar absorptivity and
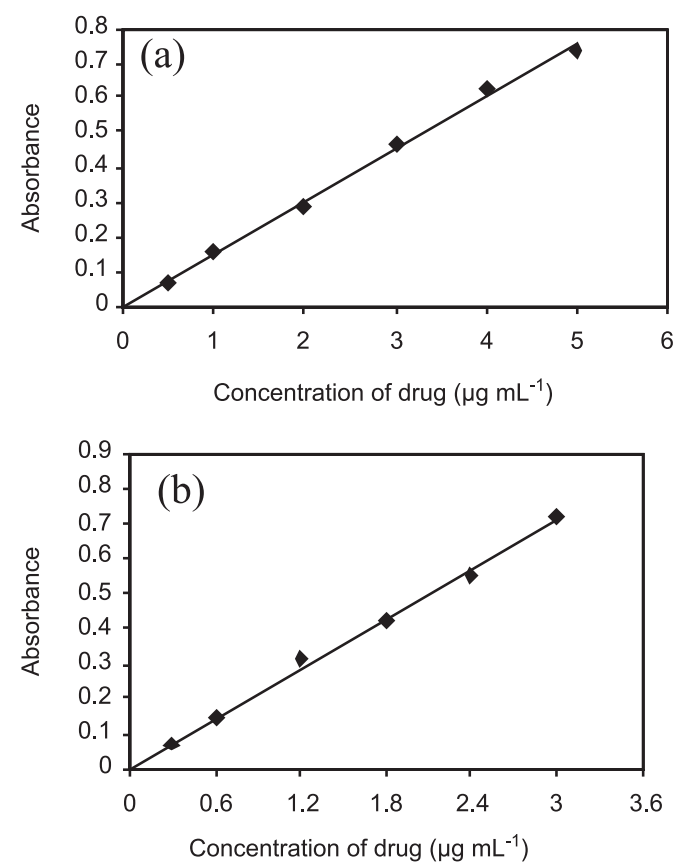

FIGURE 3 - Calibration curves for (a) method A and (b) method B). 
Sandell's sensitivity values, as well as the limits of detection and quantification, were calculated as per the current ICH guidelines (ICH guidelines, 2005) and compiled in Table II. The results attest to the sensitivity of the proposed method. The limits of detection (LOD) and quantification (LOQ) were calculated according to the same guidelines using the formulae:

$$
\mathrm{LOD}=3.3 \sigma / \mathrm{s} \text { and } \mathrm{LOQ}=10 \sigma / \mathrm{s}
$$

where $\sigma$ is the standard deviation of five reagent blank determinations, and $\mathrm{s}$ is the slope of the calibration curve.

\section{Precision and accuracy}

In order to evaluate the precision of the proposed methods, solutions containing three different concen- trations of the OFX were prepared and analyzed in five replicates. The analytical results obtained from this investigation are summarized in Table III. The low values of the relative standard deviation (\% R.S.D) and percentage relative error ( $\%$ R.E) indicate the precision and accuracy of the proposed methods. The percentage relative error is calculated using the following equation:

$$
\% R \cdot E=\left[\frac{\text { found }- \text { taken }}{\text { taken }}\right] \times 100
$$

The assay procedure was repeated seven times, and percentage relative standard deviation (\% R.S.D) values were obtained within the same day to evaluate repeatability (intra-day precision), and over five diffe-

TABLE II - Sensitivity and Regression Parameters

\begin{tabular}{lcc}
\hline Parameter & Method A & Method B \\
\hline$\lambda_{\max }, \mathrm{nm}$ & 610 & 530 \\
Linear range, $\mu \mathrm{g} / \mathrm{mL}$ & $0.5-5.0$ & $0.3-3.0$ \\
Molar absorptivity $(\varepsilon), \mathrm{L} / \mathrm{mol} / \mathrm{cm}$ & $5.534 \times 10^{4}$ & $9.242 \times 10^{4}$ \\
Sandell sensitivity*, $\mu \mathrm{g} / \mathrm{cm}^{2}$ & 0.007 & 0.004 \\
Limit of detection $(\mathrm{LOD}), \mu \mathrm{g} / \mathrm{mL}$ & 0.03 & 0.03 \\
Limit of quantification $(\mathrm{LOQ}), \mu \mathrm{g} / \mathrm{mL}$ & 0.09 & 0.08 \\
Regression equation, $\mathrm{Y}^{* *}$ & & \\
Intercept (a) & 0.003 & 0.003 \\
Slope (b) & 0.152 & 0.237 \\
Standard deviation of a $\left(\mathrm{S}_{\mathrm{a}}\right)$ & 0.0104 & 0.0774 \\
Standard deviation of $\mathrm{b}\left(\mathrm{S}_{\mathrm{b}}\right)$ & 0.004 & 0.046 \\
Regression coefficient $(\mathrm{r})$ & 0.998 & 0.999 \\
\hline
\end{tabular}

${ }^{*}$ Limit of determination as the weight in $\mu \mathrm{g}$ per $\mathrm{ml}$ of solution, which corresponds to an absorbance of $\mathrm{A}=0.001$ measured in a cuvette of cross-sectional area $1 \mathrm{~cm}^{2}$ and $\mathrm{l}=1 \mathrm{~cm} .{ }^{* *} \mathrm{Y}=\mathrm{a}+\mathrm{bX}$, Where $\mathrm{Y}$ is the absorbance, $\mathrm{X}$ is concentration in $\mu \mathrm{g} / \mathrm{mL}$, a is intercept, $b$ is slope.

TABLE III - Evaluation of intra-day and inter-day accuracy and precision

\begin{tabular}{lccccccc}
\hline Method $^{\mathrm{a}}$ & $\begin{array}{c}\text { OFX } \\
\text { taken }\end{array}$ & \multicolumn{3}{c}{ Intra-day accuracy and precision } & \multicolumn{3}{c}{ Inter-day accuracy and precision } \\
\cline { 3 - 7 } & 2.0 & OFX found & \%RE & \%RSD & OFX found & \%RE & \%RSD \\
\hline Titrimetry & 4.0 & 4.05 & 1.50 & 1.06 & 2.05 & 2.5 & 1.32 \\
& 6.0 & 5.94 & 1.00 & 0.95 & 5.85 & 2.75 & 0.97 \\
Spectrophotometry & & & & & & & 1.18 \\
Method A & 2.0 & 1.96 & 2.00 & 0.92 & 1.94 & 3.00 & 1.15 \\
& 3.0 & 3.03 & 1.00 & 1.14 & 3.10 & 3.33 & 1.28 \\
Method B & 4.0 & 4.12 & 3.00 & 1.02 & 3.89 & 2.75 & 1.11 \\
& 1.2 & 1.23 & 2.50 & 1.14 & 1.24 & 3.33 & 1.35 \\
& 1.8 & 1.76 & 2.22 & 1.19 & 1.75 & 2.78 & 1.23 \\
& 2.4 & 2.34 & 2.50 & 1.21 & 2.32 & 3.33 & 1.29 \\
\hline
\end{tabular}

RE. Relative error and RSD. Relative standard deviation. ${ }^{\text {an }}$ titrimetry, OFX taken/found are in $\mathrm{mg}$, whereas for spectrophotometry values are $\mu \mathrm{g} / \mathrm{mL}$. 
rent days to evaluate intermediate precision (inter-day precision).

\section{Selectivity}

The proposed methods were tested for selectivity by placebo blank and synthetic mixture analyses. A convenient aliquot of the placebo blank solution, prepared as described earlier, was subjected to analysis by titrimetry and spectrophotometry according to the recommended procedures. In all the cases, there was no interference by the inactive ingredients present in the placebo mixture.

A separate experiment was performed with the synthetic mixture. The analysis of synthetic mixture solution prepared above yielded percent recoveries which ranged from 97.72-102.9 with standard deviation of 0.95-1.23 in all the cases. The results of this study shown in Table IV indicate that the inactive ingredients present in the syn-

TABLE IV - Recovery of drug from synthetic mixture

\begin{tabular}{lcc}
\hline Method & $\begin{array}{c}\text { OFX in } \\
\text { synthetic } \\
\text { mixture taken }^{\mathrm{a}}\end{array}$ & $\begin{array}{c}\text { OFX recovered }^{\mathrm{b}} \\
\text { (Percent } \pm \text { SD) }^{\text {Titrimetry }}\end{array}$ \\
& 2.0 & $102.4 \pm 1.23$ \\
Spectrophotometry & 6.0 & $101.7 \pm 1.21$ \\
Method A & 2.0 & $102.9 \pm 1.18$ \\
& 3.0 & $97.84 \pm 1.14$ \\
Method B & 4.0 & $97.18 \pm 1.09$ \\
& 1.2 & $99.62 \pm 0.95$ \\
& 1.8 & $100.9 \pm 1.12$ \\
& 2.4 & $99.17 \pm 1.18$ \\
\hline
\end{tabular}

${ }^{a} \mathrm{mg}$ in titrimetry and $\mu \mathrm{g} / \mathrm{mL}$ in spectrophotometry. ${ }^{b}$ Mean value of five determinations

TABLE V - Results of analysis of tablets by proposed methods thetic mixture did not interfere in the assay. These results further demonstrate the accuracy, as well as the precision, of the proposed methods.

\section{Application to formulations}

In order to evaluate the analytical applicability of the proposed methods to the quantification of OFX in commercial tablets, the results obtained by the proposed methods were compared to those of the reference method (BP, 2003) by applying Student's $t$-test for accuracy and the $F$-test for precision. The reference method involved the titration of OFX in anhydrous acetic acid with acetous perchloric acid to potentiometric end point detection. The results (see Table V) show that the Student's $t$ - and $F$-values at a $95 \%$ confidence level are lower than the tabulated values, thereby confirming good agreement between the results obtained by the proposed methods and the reference method, with respect to accuracy and precision.

\section{Recovery studies}

The accuracy and validity of the proposed methods were further ascertained by performing recovery studies. Pre-analysed tablet powder was spiked with pure OFX at three concentration levels $(50,100$ and $150 \%$ of that in tablet powder) and totals then determined by the proposed methods. In all cases, the added OFX recovery percentage values ranged from $98.50-102.5 \%$ with a standard deviation of 1.03-1.24 (Table VI), indicating good recovery and absence of interference from the co-formulated substance in the determination.

\section{CONCLUSIONS}

The proposed titrimetric method is a first report on the application of titrimetry for the assay of OFX. The

\begin{tabular}{|c|c|c|c|c|c|}
\hline \multirow{3}{*}{$\begin{array}{c}\text { Tablet Brand } \\
\text { name }\end{array}$} & \multirow{3}{*}{$\begin{array}{l}\text { Label claim, } \\
\text { mg/tablet }\end{array}$} & \multicolumn{4}{|c|}{ Found $^{*}($ Percent of label claim \pm SD) } \\
\hline & & \multirow{2}{*}{$\begin{array}{l}\text { Reference } \\
\text { method }\end{array}$} & \multirow{2}{*}{ Titrimetry } & \multicolumn{2}{|c|}{ Spectrophotometry } \\
\hline & & & & Method A & Method B \\
\hline Zenflox- $400^{* *}$ & 20 & $100.12 \pm 1.09$ & $\begin{array}{c}102.0 \pm 1.17 \\
\boldsymbol{t}=2.62 \\
\boldsymbol{F}=1.15\end{array}$ & $\begin{array}{c}98.12 \pm 1.29 \\
\boldsymbol{t}=2.65 \\
\boldsymbol{F}=1.40\end{array}$ & $\begin{array}{c}98.87 \pm 1.15 \\
\boldsymbol{t}=1.76 \\
\boldsymbol{F}=1.11\end{array}$ \\
\hline Ofloxin- $400^{* * *}$ & 20 & $100.4 \pm 1.02$ & $\begin{array}{c}101.7 \pm 1.04 \\
\boldsymbol{t}=1.99 \\
\boldsymbol{F}=1.04\end{array}$ & $\begin{array}{c}98.95 \pm 1.32 \\
\boldsymbol{t}=1.96 \\
\boldsymbol{F}=1.67\end{array}$ & $\begin{array}{c}102.1 \pm 1.13 \\
t=2.49 \\
F=1.23\end{array}$ \\
\hline
\end{tabular}

${ }^{*}$ Mean value of five determinations. ${ }^{* *}$ Mankind Pharma Pvt Ltd., New Delhi, India; ${ }^{* * *}$ J. B. Chemicals and Pharmaceuticals Ltd, Mumbai, India. The value of $\mathrm{t}$ (tabulated) at $95 \%$ confidence level and for four degrees of freedom is 2.77 . The value of $\mathrm{F}$ (tabulated) at $95 \%$ confidence level and for four degrees of freedom is 6.39 . 
TABLE VI - Accuracy assessment by recovery experiments

\begin{tabular}{lccccc}
\hline Method & Tablet studied & OFX in tablet* & Pure OFX added* & Total found* & $\begin{array}{c}\text { Pure OFX } \\
\text { recovered } \\
\text { Percent } \pm \text { SD }\end{array}$ \\
\hline Titrimetry & Ofloxin-400 & 3.05 & 1.5 & 4.57 & $101.3 \pm 1.03$ \\
& & 3.05 & 3.0 & 6.07 & $100.7 \pm 1.08$ \\
Spectrophotometry & 3.05 & 4.5 & 7.54 & $99.78 \pm 1.17$ \\
Method A & & & & \\
& Ofloxin-400 & 1.98 & 1.0 & 2.97 & $99.00 \pm 1.24$ \\
& & 1.98 & 2.0 & 3.95 & $98.50 \pm 1.07$ \\
Method B & 1.98 & 3.0 & 4.97 & $99.67 \pm 1.03$ \\
& Ofloxin-400 & 1.22 & 0.6 & 1.83 & $101.6 \pm 1.15$ \\
& & 1.22 & 1.2 & 2.45 & $102.5 \pm 1.04$ \\
\hline
\end{tabular}

"mg in titrimetry and $\mu \mathrm{g} / \mathrm{mL}$ in spectrophotometry. ${ }^{* *}$ Mean value of three measurements.

titrimetric method is straightforward and fast compared to the other methods reported earlier. The proposed methods make use of simple reagent, which an ordinary analytical laboratory can afford and, unlike most currently available spectrophotometric methods, the present methods are free from unwelcome steps such as heating or extraction and also from critical $\mathrm{pH}$ conditions. The spectrophotometric methods are the most sensitive reported to date for OFX (Table I). The methods are also useful for their high tolerance limit for common excipients found in drug formulations. These merits, coupled with the use of simple and inexpensive instruments, allow recommendation of the use of these methods in routine quality control Laboratories.

\section{ACKNOWLEDGEMENTS}

The authors wish to acknowledge Cipla India Ltd, Mumbai, India, for providing the gift sample of ofloxacin. One of the authors (OZD) also wishes to thank the University Grant Commission (UGC), New Delhi, for the award of the UGC Meritorious Research Fellowship, while two of the authors (OZD and KBV) also thank the authorities of the University of Mysore for their kind permission and facilities to carry out the research work.

\section{REFERENCES}

ABDALLA, A.E.; BAHRUDDIN, S.; ABDUSSALAM, S.M.I.; MUHAMMAD, I.S.; HASSAN, Y.A. Determination of ofloxacin enantiomers in pharmaceutical formulations by capillary electrophoresis. J. Liq. Chromatogr. Rel. Technol., v.31, p.348-360, 2008.
ARJEKAR, A.P.; KAPADIA, U.S.; RAJ, S.V.; KUNJIR S.S. Quantitative determination of lomefloxacin, ofloxacin, pefloxacin and enrofloxacin in pharmaceutical dosages, bulk drug and processes monitoring of enrofloxacin by HPLC-RP. Indian Drugs, v.33, p.261-266, 1996.

BERKA, A.; VULTERIN, J.; ZYOKA, J. Newer redox titrants. New York: Pergamon Press, 1965. p.53.

BRITISH PHARMACOPEIA. Her Majesty's Stationery office, London, 2003. v.3, p.1357.

CARLUCCI, G.; MAZZEO, P.; FANTOZZI, T. Determination of ofloxacin in pharmaceutical forms by highperformance liquid chromatography and derivative UVspectrophotometry. Anal. Lett., v.26, p.2193-2201, 1993.

DRLICA, K.; ZHAO, X. DNA gyrase, topoisomerase IV, and the 4-quinolones. Microbiol. Mol. Biol. Rev., v.61, p.377392, 1997.

EBOKA, C.J.; AIGBAVBOA, S.O.; AKERELE, J.O. Colorimetric determination of thr fluoroquinolones. $J$. Antimicrob. Chemother., v.39, p.639-641, 1997.

FRANCIS, P., ADCOCK, J.L. Chemiluminescence methods for the determination of ofloxacin. Anal. Chim. Acta, v.541, p.3-12, 2005 .

HASSAN, A.; IBRAHIM, R.; IBRAHIM, D.; MOSTAFA, M. Evaluation of N-Bromosuccinimide as a new-analytical reagent for the spectrophotometric determination of fluoroquinolone antibiotics. Chem. Pharm. Bull. (Tokyo), v.55, p.1551-1556, 2007. 
HALKAR, U.P.; ANKALKOPE, P.B. Reverse phase highperformance liquid chromatographic determination of ofloxacin and tinidazole in tablets. Indian Drugs, v.37, p.585-588, 2000.

\section{INTERNATIONAL CONFERENCE ON HARMONISATION} OF TECHNICAL REQUIREMENTS FOR REGISTRATION OF PHARMACEUTICALS FOR HUMAN USE, ICH Harmonised Tripartite Guideline. Validation of Analytical Procedures: Text and Methodology, Q2 (R 1), Complementary Guideline on Methodology dated 06 November 1996, London, incorporated in November 2005 .

ISSA, Y.M.; ABDEL-GAWAD, F.M.; ABOU TABLE, M.A.; HUSSEIN, H.M. Spectrophotometric determination of ofloxacin and lomefloxcin hydrochloride with some sulphonthalien dyes. Anal. Lett., v.30, p.2071, 1997.

KALTA, R.R.; SHARMA, R.; CHATURVEDI, S.C. Simultaneous RPHPLC determination of nitazoxanide and ofloxacin in combined tablet dosage foerm. Indian $J$. Pharm. Sci., v.70, p.491-494, 2008.

MATHUR, S.C.; KUMAR, Y.; MURUGESAN, N.; RATHORE, Y.K.S.; SETHI, P.D. Spectrophotometric determination of ofloxacin in pharmaceutical formulations. Indian Drugs, v.29, p.376, 1992.

MORRISON, R.T.; BOYD, R.N. Organic chemistry. 6.ed. New Jersey: Prentice-Hall, 2007. p.390.

PATEL, P.U.; SUHAGIA, B.N.; PATEL, M.M.; PATEL, G.C.; PATEL, G.N. Spectrophotometric determination of ofloxacin with citric acid-acetic anhydride. Ind. Pharm., v.6, p. 59-61, 2007.

SALEM, H. Spectrofluorimetric, atomic absorption spectrometric and spectrophotometric determination of some fluoroquinolones. Am. J. Appl. Sci., v.2, p.719-729, 2005.
SASTRY, C.S.P.; RAMA RAO, K.; SIVA PRASAD, D. Extractive spectrophotometric determination of some fluoroquinoline derivatives in pure and dosage forms. Talanta, v.42, p.311-316, 1995.

SASTRY, C.S.P.; RAMA RAO, K.; SIVA PRASAD, D. Spectrophotometric determination of enrofloxacin and ofloxacin in pharmaceutical formulations. Indian Drugs, v.32, p.172-175, 1995.

SHINDE, V.M.; DESAI, B.S.; TENDOLKAR, N.M. Selective determination of fluoroquinolone derivatives fron tablets by reverse - phase HPLC. Indian Drugs, v.35, p.715-717, 1998.

SILVERIA, E.V.L.; SCHAPOVAL, E.E.S. Microbiological assay for determination of ofloxacin injection. J. Pharm. Biomed. Anal., v.1-2, p.91-96, 2002.

SRIVIDYA, P.; CARDOZA, R.M.; AMIN, P.D. Stability indicating HPTLC method of ofloxacin. Indian Drugs, v.40, p.41-43, 2003.

SUN, S.W.; WU, A.L. Determination of fluoroquinolone antibacterials in pharmaceutical formulations by capillary electrophoresis. J. Liq. Chromatogr. Rel. Technol., v.22, p.281-296, 1999.

TAMER, M. Adsorptive stripping voltammetric determination of ofloxacin. Anal. Chim. Acta, v.231, p.129-131, 1990.

TUNCEL, M.; ATKOSAR, Z. Determination of ofloxacin in tablets by potentiometry and conductometry. Pharmazie, v.47, p.642-653, 1992.

UNITED STATES PHARMACOPOEIA, National Formulary XVII, Rockville: USA Convention, 1990. v.22, p.912.

ZHOU, G.; PAN, J. Polarographic and voltammetric behaviour of ofloxacin and its analytical applications. Anal. Chim. Acta, v.307, p.49-53, 1995.

Received for publication on $05^{\text {th }}$ January 2010 Accepted for publication on $15^{\text {th }}$ February 2011 